\title{
The Revitalization of Iconic Shapes through the Creation of Relief Dimensional Paintings as Tourism Software Products (Case Study in Medan City, Indonesia)
}

DOI: https://doi.org/10.47175/rissj.v2i4.291

\begin{tabular}{|c|c|}
\hline Zulkifli $^{1 *} \mid$ Anam Ibr & Mangatas Pasaribu ${ }^{3}$ | Bakhrul Khair Amal ${ }^{4}$ | \\
\hline $\begin{array}{l}\text { 1,2,3Faculty of Languages and } \\
\text { Arts, Universitas Negeri } \\
\text { Medan, Indonesia } \\
\\
{ }^{4} \text { Faculty of Social Science, } \\
\text { Universitas Negeri Medan, } \\
\text { Indonesia } \\
\text { *zulkiflifbs@unimed.ac.id }\end{array}$ & $\begin{array}{l}\text { ABSTRACT } \\
\text { Medan City in Indonesia, is rich with iconic forms in the form of } \\
\text { historical buildings and cultural products of the past. On the other } \\
\text { hand, Medan City tourism has been known since the Dutch } \\
\text { colonial era, but has not been supported by the availability of } \\
\text { souvenir products. This research article describes the } \\
\text { revitalization of the iconic forms of Medan City. The aim is to } \\
\text { examine the potential of iconic forms to be used as the basis for } \\
\text { the development of relief-dimensional painting as a tourism } \\
\text { souvenir product. This research use desciptive qualitative } \\
\text { approach. The replicated method is a combination of survey } \\
\text { method and creation method. Sources of research data are } \\
\text { written data, photo data, interview results, notes on the creation } \\
\text { process, and appreciative assessments. Data analysis was carried } \\
\text { out using an interactive model: data reduction, data presentation, } \\
\text { verification and conclusion drawing. The results showed that the } \\
\text { iconic shapes of Medan City have great potential to be explored } \\
\text { into original painting themes. Technically, the art of painting with } \\
\text { relief dimensions is effectively developed with rubber sheet } \\
\text { material, supported by strong texture work. Overall, the paintings } \\
\text { produced have an aesthetic quality, exclusive as tourism } \\
\text { souvenirs. } \\
\text { KEYWORDS } \\
\text { revitalization; iconic shapes; relief-dimensional paintings; } \\
\text { souvenir products }\end{array}$ \\
\hline
\end{tabular}

\section{INTRODUCTION}

Medan City is one of the big cities in Indonesia, which is the third largest city after Jakarta and Surabaya, with a population of 2,229,408 people (http://perkotaan. bpiw.pu.go.id/v2/kota-besar/93). Medan City is also the capital of North Sumatra, an area that has natural beauty and rich cultural diversity. Because of this natural beauty and cultural diversity, Medan City in particular and North Sumatra in general have been visited by European tourists since the 1920s (Damanik, 2014). Famous as a tourist destination since the Dutch colonial era are Brastagi, Lake Tona (Parapat), Nias, and the city of Medan. Along with the times, Medan City continues to grow, where after independence it became a city of industry and trade, with a heterogeneous and multi-ethnic population. The existence of Medan City is also very strategic, because it is close to neighboring countries Malaysia and Singapore.

The tourism history of Medan City is not in line with the development of its supporting elements, especially the existence of souvenir products. Whereas the existence of unique souvenirs really supports the progress of tourism, to treat the memory of tourists who have visited. Surveys conducted in several places selling eye injury products, for example in the 
central market of Medan and around the Maimun Palace, seem to generally sell products of a general nature. The products in question are ceramics, wickerwork, and handicrafts made from wood and cloth. Some of them are imported from Yogyakarta, such as batik and wooden crafts. Moreover, the products marketed in modern markets such as malls, are all products without a local identity, which are sold everywhere.

It is necessary to develop an exclusive form of souvenirs with the identity of the local characteristics of Medan City. For its development, there are actually many references that can be used as a source of inspiration. Many iconic forms are already known to the public as markers and markers of the city of Medan, for example various architectural forms and socio-cultural products of the past. Efforts should be made to create a database about the iconic forms of the city of Medan. As best practices, many souvenirs of London City have been developed from the form of city buses, telephone boxes, and monumental buildings that are icons of London City.

There are many creative human resources for the development of Medan City souvenir products. Besides those who are educated as fine arts students or vocational school students, there are also creative communities who can develop creative industries. Therefore, based on the various potentials that exist, it is necessary to develop a special form of souvenirs to support tourism in Medan City.

In this study, souvenir products were developed through the creation of reliefdimensional paintings, by taking references to various iconic forms of Medan City. This relief-dimensional painting is visualized on tafril made of rubber, by making it layered, so that the dimensions of the relief are impressive. To give the impression of a strong texture, the image of the object and its contours is worked out firmly using a tool in the form of a soldering iron. As a unique and exclusive product, souvenir products like this don't exist anywhere else.

To support the practicality of the product so that it is easy to move, it is packaged in a size that is easy to carry or enter the trunk of a vehicle. Then for security and durability, on the back side of the painting product a rigid material such as thin plywood is applied. This product can be prepared in multiple forms with various possible compositions, to accommodate the wishes of consumers to be able to create their display compositions.

The development of relief-dimensional painting based on iconic forms is expected to be a solution for the procurement of souvenir products typical of Medan City. This is very important, because wherever tourism is developed, it is always supported by the contribution of souvenir products (Rahajeng, 2015). This effort is also a synergy in problem solving, which is related to the revitalization of Medan City icons as an effort to preserve the identity of the local socio-cultural environment. Then, synergize with the development of the creative economy in order to support the tourism world of Medan City. In other words, it is an organic combination and the integration of tourism with culture, which encourages an increase in tourism products and the tourism economy (Hao, 2017).

\section{LITERATURE REVIEW}

\section{The Iconic Shape of Medan City}

The definition of iconic is often understood in semiotics, namely the science of the relation of signs. Iconic forms are shapes that represent certain objects or characters (Budiman, 2011). Thus, the iconic shape will become the identity of the shape or character it represents. The city of Medan has forms that can be categorized as iconic forms, namely something that has become monumental or legendary so far. In the architectural category (historical buildings) there are buildings such as the Maimun palace, the Al Mashun mosque, the 
Tirtanadi tower, the Tjong A Fie building, colonial heritage buildings such as the post office, the London Sumatra building, and buildings in the Kesawan area of Medan. In the category of means of transportation, there are already legends of motorized tricycles (betor) or Medan paddle rickshaws, which are unique and different from pedicabs in other places.

In Medan, there are many old Dutch heritage buildings. The arrival of the Dutch or Europeans to Medan to travel has been a lot since the colonial era. So it's not surprising that Medan is also dubbed as Parijs van Sumatra (Yasyi, 2020). This Dutch heritage building, and the glorious Malay Deli building are icons of Medan City that must be preserved.

Although the existence of this iconic form has become legendary as a marker and marker for Medan City, as a tourism souvenir product it has not been explored. Souvenirs that are widely marketed in Medan are general products, which do not specifically represent the identity of Medan City. Through this research, we develop it in the form of painting with relief dimensions. Many artistic sides or viewpoints of iconic forms can be explored. So that efforts to preserve and promote the iconic forms of the city of Medan continue, development models are also made.

\section{Tourism Painting}

The understanding of painting is very diverse, but the most common explains that painting is an expression of aesthetic expression of the artist as outlined in a two-dimensional field (Santo, 2012). In line with the development of the art discourse, this understanding shifted so that it gave birth to contextual meanings. In the development of art theory, initially it was recognized that the grouping of fine art was in the categories of fine art and applied art. However, since the development of contemporary art, various alternatives have emerged, these groupings have begun to melt away. Painting is no longer merely a two-dimensional flat, and its orientation develops in various aspects, from conceptual to functional. Especially since the development of commercial art within the framework of the creative economy, painting has become market-oriented. In this case, besides being aesthetically oriented, painting is also functional. Painting in relation to the world of tourism is part of a functional concept within the framework of the creative economy.

To support tourism in Medan City, researchers have developed alternative paintings, namely by conducting exploration to give birth to new characters of painting in Medan City. So far, paintings are made in flat format on canvas in the form of tafril, and are oriented as products of aesthetic expression, as understood from the results of previous research on painting. Through this research, relief-dimensional painting was developed, which is not only aesthetically oriented but also functional as a tourism product. In addition to technical and aesthetic development, the theme is also developed as a painting content, by revealing the iconic forms of Medan City. This painting is manifested in the tendency of realist or surrealist forms, so that the essence of the iconic form is communicated more straightforwardly to the appreciator community.

This relief-dimensional painting was developed based on the principles of tourism. The object is a representation of the iconic forms of Medan City, made in a simple form, so that it is practical in mobility, developed in various variations and compositions, and with a relatively cheap price calculation. Moreover, apart from being a tangible souvenir product, this product is loaded with a socio-cultural mission, namely introducing Medan City through its identity, which in turn will promote Medan City tourism.

By definition, tourism souvenirs are products that are produced and consumed in relation to tourism (Zulkifli, 2010). One of the components in the progress of tourism in an area is the presence of souvenirs. In this regard, the expected souvenirs are those that represent the local social and cultural environment. Tourism souvenirs are objects that connect mentally 
(memory, fantasy, imagination) a person about the tourist areas he has visited (Causey, 2006).

As a tourism product, souvenirs have practical principles to carry (Yulianto, 2015). More fully, Atmojo (2007) says: the characteristics of tourism souvenir products are: 1) imitation of the original; 2) short, compact, or miniature form of the original; 3) full of variety; 4) the sacred, magical, and symbolic values are left behind; and 5) relatively cheap price.

Research conducted on tourism souvenirs so far, especially in Medan and North Sumatra, is related to two things, namely the form of cultivation and the reference base. The form of work developed generally is in the form of exploration of batik, ceramics and handicrafts in general, as can be understood in the research of Wahyu Tri Atmojo and Dermawan Sembiring. The reference base is generally North Sumatran ethnic ornaments and artifacts. No one has yet developed a form of painting based on the iconic forms of the city of Medan. Especially those who explore it in the form of painting with relief dimensions.

In the Indonesian perspective, the area that has a characteristic with a two-dimensional form of painting or work is Bali, then Cirebon. Bali has a distinctive style of perspective in giving birth to the impression of space in two-dimensional works, and Cirebon has a unique form of glass painting. What is common in various places is the form of calligraphy works, also widely marketed in Medan City. Products that are general in nature, of course, do not represent a particular area, so they cannot be souvenir products (Rahajeng, 2015; Pelly, 2015). Through the development of souvenirs in the form of paintings with relief dimensions in this study, it is hoped that Medan City has a distinctive new form of souvenirs, like Bali and other regions with their own characteristics.

\section{RESEARCH METHODS}

As an art research from a sociological perspective, this research uses a descriptivequalitative approach. The method developed is a combination of survey method and creation method, which is carried out in a structured and systematic manner. The survey method was applied when collecting data on the potential for the iconic shapes of Medan City, by classifying them based on the character of the representative shapes. Next, when collecting appreciative responses by observers and the public on the quality of painting products with relief dimensions as a result of development, through exhibition activities and appreciative discussions, they were held.

The method of creation was developed referring to Graham Wallas' theory of creativity. This method describes the creation process starting from preparation, incubation, illumination, execution, confirmation, validation, and development (Wallas in Damajanti, 2006: 23). -24). Research data were collected from various sources, in the form of written data, photo data, interviews, and notes on the creation process, as well as appreciative assessments. Research informants are experts who understand the history of Medan City, and art observers and the public who witnessed the exhibition.

Data was collected through literature studies, field observations, documentation, discussions and interviews with resource persons (informants), daily recording, and distribution of appreciative response instruments. Prior to the creation process, data was collected on the iconic shapes of Medan City. This activity was carried out through observation, photo recording, supported by interviews and discussions, and literature studies. After the creation process, data collection on aesthetic quality assessment was carried out based on the appreciation of observers and the public when exhibitions and discussions were held. Descriptive-qualitative in this case emphasizes the appreciative aspect, the extent to which paintings can support the development of Medan City tourism souvenir products. The creation process data is collected through daily recording and careful 
recording. So that all of these data are guaranteed to be valid, they are tested through data triangulation, namely by comparing data obtained from various sources. Then, the interpretation of the data and the drawing of research conclusions were carried out according to the interactive model, namely data reduction, data presentation, and conclusion drawing or verification.

\section{RESULTS AND DISCUSSION}

\section{The Potential of Iconic Forms}

From the various iconic forms of Medan City which include architecture (historical buildings) and socio-cultural products that have become the identity of Medan City, the researchers took samples of 12 representative forms, namely: Maimun Palace, Al Mashun Grand Mosque, Tirtanadi Tower, Post Office, Old Town Hall, Train Station, London Sumatra Building, Tjong A Fie's House, Kesawan Square, motorized rickshaws, rowing rickshaws, and sudako. Maimun Palace is the palace of the Deli Malay Sultanate, built in 1891, in an eclectic style blending Malay, Islamic and European architecture. The overall form is Malay, depicting a stilt building, having stairs and a veranda at the front. The elements of Islamic architecture are in the shape of the dome and arches around the building as well as on the inside, and the European feel is seen in the shape of the doors and windows. The potential development in relief-dimensional painting is in the form of the whole and its parts. Visualization of the overall form, especially from a three-quarters point of view is very artistic, as it displays dynamic contours. Parts or elements of the building that also have artistic potential to be explored with relief dimensions are curved shapes, whether curved outside or inside the room.
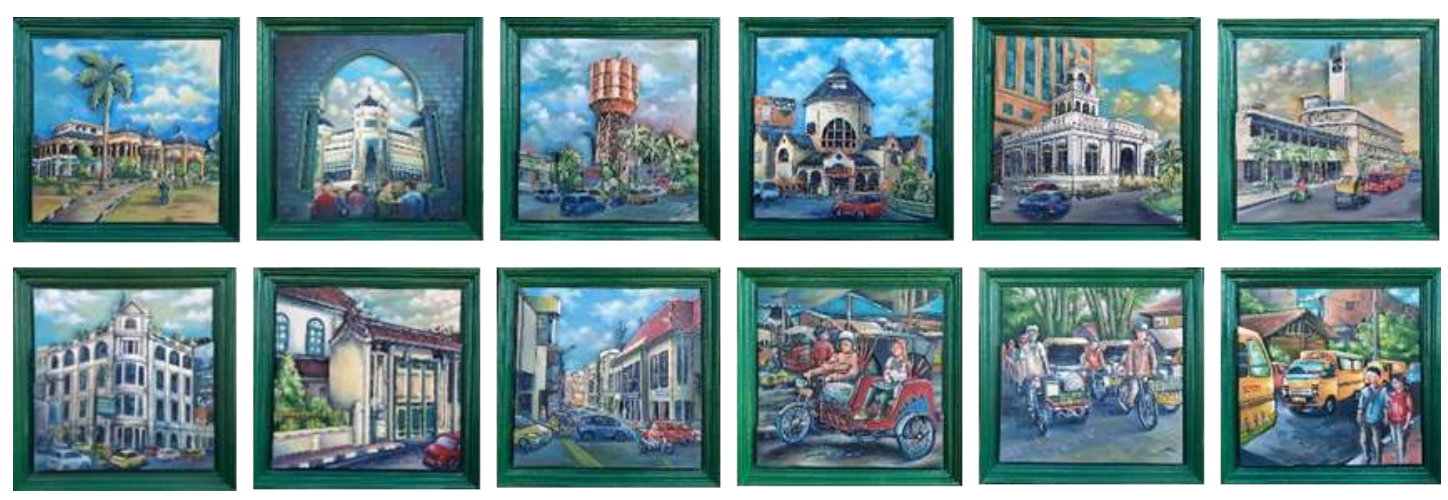

Figure 1. Photo Painting Revitalization of Medan's Iconic Forms

Relevant to the Maimun Palace, is the characteristic of the Al Mashun Grand Mosque. The Malay kingdom/sultanate is an Islamic empire, therefore, the existence of a mosque is inseparable. The existence of the Al Mashun Grand Mosque is a testament to the glory of the Malay Deli in the past. The Maimun Palace and the Al Mashun Grand Mosque are the cultural identities of the Malays in the city of Medan (Rudianto, \& Anshori, 2020). Masjid Raya Al Mashun was built in 1909, in the style of the Middle East and Europe, symmetrical octagon shape, looks majestic and majestic from various directions. Besides the main building, it is equipped with a building for ablution, towers, and gates.

The potential for development in painting with relief dimensions is in the contours of the dome and building facades, especially the arches and columns that show depth. The visualization contour of the top of the building is getting more dynamic by including the shape of the tower. Not only the main building of the mosque, the entrance gate of the 
mosque also has strong artistic potential. In this case, the artist can create a centralized relief dimension, which is surrounded by a gate arch.

The next iconic form is the Tirtanadi Tower, which stands at the intersection of Sisingamangaraja Street and Pandu Medan Street. This water tower was once owned by a Dutch company, built in 1908. Visually, this building is very distinctive, so it has the potential to be explored as a work of painting with relief dimensions. The towering shape gives birth to contour lines that contrast with the sky background. In addition, the supporting pillars have cavities, which also have the potential to cause relief dimensions.

Entering the 20th century, many buildings and monumental buildings were built in the city of Medan. Around Merdeka Square, which is declared as the city center (zero point) of Medan City, many monumental buildings stand. This building serves as government offices, companies, and public services. Some of them are used as objects of this research, namely the Post Office which was built in 1911, the old City Hall which was built in 1908, the Railway Station which was inaugurated in 1886, and the London Sumatra (Lonsum) rubber plantation office building which was built in 1909. Now around the Field Merdeka is considered an instagramable location. In this case, architecture plays a major role in branding the city, through images and the spread of instagramable photogenic iconic architecture (Kim, 2019).

All of the buildings above have become icons of Medan City, and have the potential to be used as the basis for the development of painting with relief dimensions. The Medan Post Office is in a strategic location, interesting from the point of view of the City Hall road. Likewise with the old City Hall offices, each of which stands out because it is not adjacent to the surrounding buildings. The Railway Station building is on the east side of Merdeka Square. This building is elongated, is a relic of the Dutch era that has been renovated. The artistic impression of this building is in the form of the manara, which creates dynamic and firm contour lines against the background. Almost all buildings make protruding shapes on the roof or at the top of the building, including the old Post Office and Town Hall buildings. Unlike the London Sumatra Building, its position is close to the building beside it. This building utilizes the point of view from the direction of Merdeka Square, so that the protrusion and emphasis of its shape are also made at an angle. The potential dimensions of the relief to be developed in painting are the contours of the top of the building and the repetition of the window cavities seen on the building facade.

An iconic building in the Ancient Chinese style is the Tjong A Fie Mansion, standing on Jalan Jend. Ahmad Yani Medan. This building was built in 1900 by Tjong A Fie who came to Medan from Guangdong in 1875. A successful millionaire thanks to his cooperation and good relationship with the Sultan of Deli. The Tjong A Fie building has the potential for relief dimensions, including from the front view of the entrance gate. Between the gate and the main building there is space, so it is very artistic to work on painting with relief dimensions. Another potential is in the parts of the building and the indoor point of view.

The existence of the Tjong A Fie building contrasts with other buildings in the Kesawan area of Medan. Another building is a historic building from the Netherlands which became an icon of Medan City. The difference is that the Dutch heritage building has a European art deco style, while Tjong A Fie has an Ancient Chinese style. The uniqueness of the contours of the buildings in the Kesawan area is in the height and low of the building and the forward or backward position of the building, especially seen from along Jalan Jend. Ahmad Yani. The uniqueness of this contour has the potential to be worked on in painting with relief dimensions.

The iconic form of Medan City that is no less interesting is the means of transportation, as a socio-cultural product. The means of transportation in Medan City in the past were 
motorized rickshaws, oars and sudako. The motorized rickshaw, which is often abbreviated as betor, is very distinctive, in contrast to the becak in Java which is generally rowed by humans. While in Medan rowing rickshaw is also typical, where the rower is beside the passenger, while the pedicab in other places is generally behind the passenger.

Sudako is a means of transportation in the form of a car, as a city transportation. This Sudako also has a distinctive shape, where the passenger cabin space is separate from the driver. From the outside, it is clear the difference between the passenger room and the driver's room. The passenger seat only extends parallel to the wall, and the passenger door is made at the back. All forms of transportation in the past in Medan have the potential to be explored in painting with relief dimensions, as tourism souvenirs.

\section{Exploration of Painting Techniques with Relief Dimensions}

Technical exploration starts from the preparation of materials and tools, the painting process, to finishing. The basic material used as a painting tafril is a rubber sheet. In the market there is a choice of thickness, just adjust it according to your needs. The thickness of $1 \mathrm{~cm}$ is ideal for two-layer relief dimensions. But if the relief layer is more, you can use a thinner rubber. The rubber material used is to make it easy to bring up the dimensions of the relief and work on the surface of the painting. More than that, with rubber it is easy to work on the texture, namely by using a heat-conducting tool in the form of a soldering iron.

The rubber sheet is affixed to the plywood base that has been prepared in advance, complete with the frame. The shape of this frame can be square or square, according to the character of the object of the painting. The thickness and strength of the plywood is adjusted to the size of the painting area. For paintings as souvenirs, only 2 or $3 \mathrm{~mm}$ thick plywood is enough. The triple frame is made of profiled wood, the shape of which is also adjusted to the size of the painting area and the thickness of the rubber layer. This frame is painted first before the rubber sheet is attached, and after finishing time it can be repainted to make it cleaner. The profiled wood frame is not only a protection for the surroundings, but also a protection for the painting surface. Therefore, the thickness of the profile frame should exceed the thickness of the rubber layer. The profile frame secures the third painting to be carried, for example to be exhibited or packaged for consumers.

The rubber sheet is attached to the framed plywood base with white glue (PVAC glue). The process is pressed for one day. The first layer sheet is pasted first, which will later become the basis for the remote view object. Then the second layer, which will be the base of the close-up object. Before being pasted, the second layer already has a global sketch, so that when the contours of the object are cut, they have an image of the real object. The second sheet is primed before pasting, so that it is easy to distinguish near and far objects. With these two layers of rubber, the dimensions of the relief on the tafril of the painting have been born.

To strengthen the dimensions of the relief, it is supported by texture work, which is also made when visualizing the object of the painting. The texture is made with a heat conducting tool, which is already available in the market is a soldering iron. Next is the cultivation of paintings with oil or acrylic paints. The technique used can be a brush or a palette technique, the important thing is that the brushstroke is made stronger and the color is slightly contrasting.

\section{Aesthetic Exploration of Painting with Relief Dimensions}

As with Graham Wallas' theory of creativity, exploration of iconic forms in reliefdimensional painting includes the processes of incubation, illumination, execution, and 
confirmation. This process starts from considering the point of view of the object of the painting, namely the iconic shape of the city of Medan. Objects can be framed as a whole, i.e. as a whole, or take part of an object that looks artistic. Taking part of an object or determining an unusual point of view requires its own foresight. Sometimes things like this give birth to unexpected aesthetic qualities. For example, on the iconic object of the Al Mashun Grand Mosque, the corner of the field from below the entrance gate looks artistic. Likewise with certain parts of the space in the Maimun Palace, which is unique and artistic.

Framing of objects is related to the pattern of painting tafril, for example a square or rectangle. In this exploration of painting, tafril is prepared from scratch with a frame, which is then pasted with a layer of rubber. The dimensions of the relief are realized with a layer of rubber, a minimum of two layers. The principle thing is to determine the contour of the rubber layer as a barrier between distant and near objects. The first rubber layer is intended for distant objects, and the second rubber layer is for near objects. The artistic quality is largely determined from these contours, where the contours that vary from high to low objects give birth to dynamic compositions. In the iconic architecture of the city of Medan itself, some have shown dynamic contours, for example by presenting a prominent shape on the roof or the top of the building. Kantar Pos Medan, for example, made the center of the roof higher, and there were variations in the height of the surrounding roof. The old City Hall features a dome-like shape that is elevated in the center of the roof. The contour of the roof or the top of this building has a great influence on the aesthetic quality of the relief dimensions being worked on.

Framing or taking the point of view of the object does not limit the visualization of the painting only to the realist form, allowing it to be explored in a surreal way. The consequences of object framing and rubber layer contours that distinguish near objects and distant objects give rise to a relief dimension pattern. There are at least two patterns, namely the staircase pattern and the circular pattern. The ladder pattern shows objects that are far away at the top of the tafril, and close objects at the bottom of the tafril. On the other hand, the circular pattern makes the object in the center as a far view, and the object at the edge as a close view.

Further exploration of iconic shapes is through the cultivation of textures to strengthen the relief dimensions. In accordance with the character of the rubber material, the texture can be made by means of a heat conductor. This texture work is in line with the formation of the object image. Textures can be made thick or thin, strong or soft, tenuous or massive, and so on according to the desired character. Next is finishing with oil or acrylic paints. Painting characters with relief dimensions and real relevant textures are completed with strong brushstrokes with contrasting colors.

The development of the aesthetic quality of relief-dimensional painting includes the process of execution, confirmation, validation, and development. The aesthetic potential of this painting is understood internally based on observations during the creation process, supported by diary data and discussions of the research team. Externally, aesthetic quality is understood based on the appreciator's responses through the distribution of questionnaires. The potential for the aesthetic quality of a painting is seen based on the development of the visual elements of painting, including elements of form that build the integrity of the work. These visual elements are those which are applied based on the principles of art. Comprehensively, the aesthetic quality of painting is understood based on intrinsic and extrinsic aspects.

Appreciators generally respond positively to all aspects asked in the questionnaire. Appreciators or respondents responded positively about the application of the principle of unity and harmony. Where the visual elements that are elementary and the elements of the 
form that are displayed look together and give birth to a harmonious impression. The response to the application of the principle of balance and the principle of rhythm was also positive. The visual rhythm that is born in the richness of painting looks dynamic, with varied forms, colors, sizes, positions, directions, and distances. Variations in various aspects that are displayed remain by maintaining the balance of the composition. In general, this painting also displays clarity or accuracy of proportion and perspective, and gives birth to uniqueness through the composition of shapes and colors that are developed. In this case, the respondents' answers ranged between "very qualified", "quality", and "fairly qualified".

In line with that, the economic potential of painting is distinguished based on the process of creation or production and the marketing process which also concerns consumer tastes. The process of creation in order to produce a painting is not the same as the painting process of an idealist artist. The creation process here is in the context of the creative industry, which considers production costs, efficiency and productivity. To produce a painting that is oriented as a souvenir product, it requires inexpensive material and equipment costs, fast processing time, an easy process that can be done together, sufficient resources, and quality results.

The economic potential in terms of marketing of painting products is that, besides being of aesthetic quality, it is relevant to the tendency of people's tastes. People, especially immigrants who visit or travel to Medan, need representative souvenirs, representing the identity of the city of Medan. This relief-dimensional painting product based on the iconic shape of Medan City is priced according to the purchasing power of the public or tourists. Unlike the price of painting as an expression of artists who only consider aesthetic exploration.

Understanding of the contribution of painting research results in the development of tourism souvenir products is obtained through discussion and distribution of questionnaires to respondents. Respondents observed the painting through the submitted photos, where previously the researcher explained the context of the contribution and the supporting indicators. The general indicators of souvenir products are the image of a certain place, simple size, easy to carry, and relatively affordable prices.

The product of painting as a result of this research imaged the city of Medan because it raised the iconic shape of Medan City as the basis for the concept. The iconic form in this case is a representative form that has long been the identity of a place. Therefore, the resulting painting has a uniqueness, which is not the same as elsewhere, and thus looks unique and exclusive. This is in line with the results of previous studies which said that attitudes towards authenticity and aesthetics affect souvenir purchase intentions (Meitiana, et al., 2019). Besides that, unlike ordinary paintings, the size of this souvenir painting is made simple so that it is easy to pack and carry. The average size is $50 \times 50 \mathrm{~cm}$ so it can fit in the trunk of a car or airplane cabin. The surface of the painting is protected with a plywood base and a profile frame that is thicker than a layer of rubber as a painting tafril, making it easy and safe to carry on a trip. Questions about the contribution of paintings to the development of souvenir products were answered by respondents with the answers "very contributing", "contributing", and "contributing enough".

\section{CONCLUSION}

All of Medan's iconic buildings have the potential to be used as the basis for the concept of developing relief-dimensional painting. Maimun Palace has the potential for development in the form of the whole and its parts. Visualization of the overall form seen from a threequarters point of view, and the curved parts of the outside and inside the room look artistic. 
Al Mashun Grand Mosque has potential in the contours of the dome and the facade of the building, especially the arches and columns that show depth. The entrance gate of the mosque also has strong artistic potential. The visually distinctive Tirtanadi Tower, potential in the towering shape of the tower, creates contour lines that contrast with the sky background.

Entering the 20th century, many buildings and monumental buildings were built in the city of Medan. Around Merdeka Square, which is considered the center of the city (zero point), many monumental buildings stand, including the Post Office, the old City Hall, the Train Station, and the London Sumatra Building. All of these buildings have become icons of Medan City, and have the potential to be used as the basis for the development of reliefdimensional painting. This potential is supported by the protrusion of the shape on the roof or at the top of the building. An iconic building in the Ancient Chinese style is the Tjong A Fie Mansion. Its existence contrasts with other buildings in the Kesawan Square area of Medan, which have European art deco style. Another form that is no less interesting is the means of transportation, as a socio-cultural product. The means of transportation in Medan in the past were motorized rickshaws, oars and sudako, which were unique and different from other places.

Technically, the basic material that is effectively explored as a painting tafril is a rubber sheet. With this material, it is easy to create relief dimensions and work on textures with a soldering iron. The rubber sheet is affixed to a plywood base that has been framed with profile wood. There are two dimensional patterns of relief, namely the staircase pattern which shows the far object cultivation at the top of the tafril and the near object at the bottom. Then, the circular pattern makes the object in the center as a far view, and at the edge as a close view. This painting is finished with oil or acrylic paint, with a strong brushstroke.

The aesthetic quality of painting as a result of development can be seen from the application of visual elements, including elements of form that build the integrity of the work. The visual elements referred to are those which are applied based on the principles of art. Respondents responded positively about the application of the principle of unity and harmony of work. Likewise with the principle of rhythm, with the cultivation of varied shapes, colors, sizes, positions, directions, and loot. This relief-dimensional painting supports the development of tourism souvenir products, and contributes to the revitalization of the iconic forms of Medan City.

\section{REFERENCES}

Atmojo, Wahyu Tri. (2007). Dampak Pariwisata terhadap Perkembangan Seni Kerajinan Kayu di Gianyar Bali 1930-2002 (Kelangsungan dan Perubahannya). Yogyakarta: Disertasi, Universitas Gadjah Mada.

Budiman, Kris. (2011). Semiotika Visual (Konsep, Isu, dan Problem Ikonisitas). Yogyakarta: Jalasutra.

Causey, Andrew. (2006). Danau Toba: Pertemuan Wisatawan dengan Batak Toba di Pasar Suvenir. Medan: Bina Media Perintis.

Damajanti, Irma. (2006). Psikologi Seni (Sebuah Pengantar). Bandung: Penerbit Kiblat

Damanik, Erond L (2014). Mencermati Kepariwisataan Sumatera Utara. Koran Analisa Medan, 30 Agustus 2014.

Hao, Z. (2017). A study on the development of cultural tourism products in Tianjin--a case of new year paintings in Yangliuqing.

Kim, J. (2019). Iconic architecture through the lens of Instagram: the case studies of the Guggenheim Museum, Bilbao and the Dongdaemun Design Plaza, Seoul. 
Meitiana, M., Setiawan, M., Rohman, F., \& Irawanto, D. W. (2019). Factors affecting souvenir purchase behavior: valuable insight for tourism marketers and industry. Journal of Business and Retail Management Research, 13(3).

Pelly, Usman. (2015). Wisata dan Penjaja Budaya, dalam Etnisitas dalam Politik Multikultural (Buku I). Medan: Casa Mesra Publishers.

Pusat Pengembangan Kawasan Perkotaan. Profil Kota Medan. in http://perkotaan.bpiw.pu.go.id/v2/kota-besar/93, 18 March 2021

Rahajeng, Anggi. (2015). Strategi Pemasaran Produk Souvenir Pendukung Desa Wisata Tinalah dan Program Bela Beli Kulon Progo. jurnal.ugm.ac.id

Rudianto, R., \& Anshori, A. (2020). News Framing on Malay Deli Culture in medan tribunnews. com Online Media. Komunikator, 12(2), 129-135.

Santo, Tris Neddy, et al. (2012). Menjadi Seniman Rupa. Solo: Metagraf.

Yasyi, Dini Nurhadi (2020). Parijs van Sumatra yang Terlupakan, dalam https://www.goodnewsfromindonesia.id/2020/08/28/parijs-van-sumatra-yang-terlupakan.

Yulianto. (2015). Kreasi Seni Sebagai Daya Tarik Wisata Budaya di Padepokan Bagong Kussudiardja Yogyakarta. Jurnal Media Wisata, 13(1), 252-266.

Zulkifli, et al. (2010). Pengembangan Desain Produk Cenderamata Pariwisata Sumatera Utara Berbasis Karakteristik Pariwisata Alam, Pantai, Dan Budaya. Laporan Penelitian Research Grant Universitas Negeri Medan. 